content and appeal of the first year science conrse. Some discussion followed, introduced by Miss Dawson, who indicated briefly the nature of the biology work in the Cleveland schools. Identification of trees, forestry problems, insect types and problems, bacteriology, and elementary problems in agriculture were indicated as topics handled. Throughout the work the viewpoint is distinctily the economic.

In the absence of the authors, Mr. Eikenberry next presented reports by Mr. Lucas and Mr. Finley. Mr. Lucas's report dealt with the results of segregating the classes in zoölogy. Mr. Finley's report presented results of experiments having as their problem the type of interest paramount in the successive years in the grades.

The session closed with these reports and adjourned at 11:30.

FATTH MCAULex,

Secretary pro tem.

\title{
REPORT OF THE MEETING OF THE MATHEMATICS SECTION OF THE CENTRAL ASSOCIATION OF SCIENCE AND MATHEMATICS TEACHERS.
}

The section met at the Technical High School, Cleveland, Ohio, Friday and Saturday, November 25 and 26 . The following business was transacted:

The question of the continuation of the Committee on Fundamentals was left to the chairman and vice-chairman for next year.

The report of the Committee on Uniform Notation in Mathematics and the Sciences, was received and the committee continued.

The report of the Committee on Results was received and the committee continued.

The Committee on Real Applied Problems was continued with a view to the continuation of the applied problem department in SCHIOoL SCTENCE AND Matemitios.

The chairman was authorized to appoint someone to confer with the editors of Schoor SCrENCE and Matrmanatics concerning reprints of the applied problems that have appeared in the magazine during the current year.

The appointment of a Publicity Committee was ordered.

It was decided that all reports of committees appointed a year in advance, must be printed and distributed before the meeting at which these reports come up for adoption and that they must be discussed at that meeting.

Mr. J. F. Millis presented a bill of $\$ 8.00$ for reprints of the Report of the Committee on Real Applied Problems. The bill was allowed and ordered paid from the money collected at the 1909 meeting.

The following officers were elected for the coming year: Chairman, Mr. R. L. Short, Technical High School, Cleveland, Obio; Vice-Chairman, Mr. I. S. Condit, Iowa Teachers' College, ,Cedar Falls, Iowa; Secretary, Miss Marie Gugle, Central High School, Toledo, Ohio.

The papers presented are reported below:

The Fundamental Reasons for Teaching High School Mathematics. Professor David Eugene Smith, New York City. Professor Smith showed that the teaching of secondary mathematics could not be justified on any ground of immediate utility. He considered the distinctive features of mathematical thought and of mathematics teaching during certain epochs of the world's progress and discussed the prospects for the future showing the need at the present time for the kind of training that mathematics gives. He said that from the standpoint of the pupil the immediate aim in the study of mathe- 
matics is pleasure, but that for the race the ultimate aim far transcends this. In particular, profit is to be derived from the study of geometry because (1) it is an exercise in logic, (2) it gives exercise in aceurate and precise thought and expression, (3) it leads to an appreciation of the dependeace of one magnitude upon another, (4) it cultivates space intention and an appreciation of and control over forms existing in the material world and (5) because of its application to mensuration. While warning against the danger of false applications of high school mathematics, Professor Smith stated his appreciation of the value of all genuine applications particularly. of a local nature.

Report of the Committee on Fundamentals. I. S. Condit, Cedar Falls, Iova, chaiman. In the absence of $\mathrm{Mr}$. Condit, the report was read by $\mathrm{Mr}$. R. I. Short of Cleveland. The report reviewed the geometry report of 1906 , the algebra report of 1907 , the unification report of 1908 , and the preliminary report of the Committee on Real Applied Problems, presented in 1909. The report stated that the fundamentals in algebra are (1) training in generalizatiou and (2) formulation of knowledge for ready use in later work, that the aim in the study of geometry is training in Iogical reasoning, and that the fundamentals in geometry are the body of definitions and assumptions which are detcrmined by the necessities encountered in making geometry a snitable pedagogical instrument rather than in building up a pure science. The report closed with a statement of the pedagogical principles that must underly the teaching of secondary mathematics.

Report of the Committee on a Uniform System of Notation in Mathematics and the Sciences. Mr. L. P. Jocelyn of Ann Arbor, Mich., chairman. Among. the recommendations made by the committee are the following: That 0 be read zero; that decimal fractions be called decimal fractions rather than decimals and that in arithmetic, at least, they be read as fractions; that $\frac{a}{b}$ be read $a$ divided $b y$, especially in primary and secondary schools; that the fundamental operations be performed with abstract numbers only; that $a^{4}$ be read a exponent 4; that ratios be written in the fractional form; that "destroy each other" be used for "cancel" in operations involving addition and subtraction; that $f$ be used instead of $a$ for the first term of progressions. The report discussed the definitions of positive and negative numbers, the use of the various symbols of operation, the various definitions of division, the possibility of the four cases, $\$ 6 \div \$ 2, \$ 6 \div 2,6 \div \$ 2$, and $6 \div 2$, the interpretation of exponeats in the fractional form, the use and the reading for the various signs of relation, aggregation, continuation, and deduction, the treatment of proportion and the names for various operations involving proportion.

The discussion that followed called attention to certain important omissions, as for example, $x=a y$ instead of $x$ varies as or is proportional to $y$.

Report of the Committee on Results. Professor C. E. Comstock, Peoria, Ill., chairman. In the absence of Mr. Comstock the report was read by Mr. H. T. McMyler of Cleveland, a member of the committee. This committee is a subcommittee of one appointed a year ago by the association to consider the scientific study of teaching problems and especially impersonal tests of methods and results. As the general committee has but recently promulgated its plans, the subcommittee has not had sufieient time to prepare anything beyond a preliminary report of progress. The report referred to the questionaire recently sent to members of this section and contained a brief summary of replies. These replies seemed to indicate that teachers test the efficiency of methods by testing pupils, and that there is little conscious effort to judge of the efficiency of one method by a comparison of the results 
of different methods. The report then discussed the difference between testing pupils and testing methods, and general aims and methods in mathematics teaching.

Aims and Tests in Algebra, a Discussion of the Report of the Committee on Results. Mr. H. L. Terry, Madison, Wis. Mr. Terry discussed three great values in algebra as an instrument in mathematical operations. These are: first, its value as an instrument in economizing thought by giving power to think in symbols rather than in complicated English expressions; second, its value as an instrument of generalization; third, its value as an instrument for simplifying calculations. Mr. Terry stated that a thorough mastery of the algebra language is essential to any real appreciation of these values and that this mastery is to be attained only by repeated exercises in translation, by frequent use of problems and by the elimination of much of the difficult and complicated work in texts.

Discussion of the Report of the Committee on Results. Mr. O. C. Carlton, Superintendent of Schools, Medina, Ohio. Mr. Carlton was very emphatic in declaring that the good work done by the association is far too limited in extent. Every science teacher and every mathematies teacher should secure the annual proceedings and profit by the abundance of material offered in the association's official organ. The diffeulty with teachers is not that they are confused by the multitude of suggestions as the report of the comraittee states, but that they are entirely ignorant of these suggestions. Mr. Carlton discussed means of testing the efficiency of aims and methods and, while commending the suggestions of the committee, gave as the final basis for judgment, the response of the pupil-not in his ability to memorize-but in his thorough mastery that is in his vital interest.

Second Report of the Committee on Real Applied Problems. Mr. J. F. Millis, Ohicago, Ill., chairman. The committee had been continued a second year to give an opportunity for testing the adaptability of the problems that have appeared for the last two years in School Sciexce and Mathematics, to secondary school uses. Mr. Millis called attention to the main features of the report which was published in the November number of ScHooc SCIENCe and Mathematics.

Discussion of the Report of the Committee on Real Applied Problems. Miss Marie Gugle, Toledo, Ohio. Miss Gugle discussed the meaning of the words real and practical as applied to problems and showed that practical probiems are not always real to the student because (1) they may require a technical knowledge that he does not possess and (2) they may deal with conditions of which he knows notbing. Fundamental principles in mathematics must be known before they can be applied to any kind of problem, for that problem is too difficult whose conditions the pupil cannot ranslate into general conditions. Caution is necessary therefore that the particular problem do not lead too far from the general. In the second place many of the problems that have appeared are too technical for general use in the average high school class of mixed pupils. The real problem committee has a more diffeult task before it than was first supposed, for it is not sufficient that they gather concrete problems that are real to men in certain occupations; these problems must be real also to boys and girls of high school age. The work of the committee is to be highly commended, but a still more thorough and extended testing of the adaptability of individual problems for use in the mixed classes of non-technical high schools, is needed.

Discussion of the Report of the Committee on Real Applied Problems. Mr. W. E. Stark, New York City. Mr. Stark was very enthusiastic in his congratulations to the section apon the report of the committee and the general success of the undertaking, the most valuable part of which he believes to be the collection of problems itself and the demonstration of the possibil- 
ity of improving the collection through coöperative effort. He discussed three considerations bearing upon the value of real problems. First, no one set of problems has superior merit under all conditions. Their use requires differentiation. The problems given should be suited to the needs of individual pupils that each may be stimulated to his best effort. Second, the success of the problems will depend in large measure on the teacher's attitude toward them. Illustrations introduced incidentally out of a full experience, are often the most effective. It is to be regretted that most high school teachers have made no study of applied mathematics. Thirdly, a knowledge of the facts and relations of formal mathematics is of little value unless they are so associated in the pupil's mind with other ideas that they will lead to a modification of his thinizing. Real problems should be used, therefore, in such a way as to make the pupil's conception of mathematical principles and methods broader in scope, to give him some recognition of the dependence of our present possessions in the way of regulariy laid out cities, of buildings, machinery, furniture, and the like, upon mathematics, and to arouse in him some respect and admiration for this wonderful possession of the people of our time.

Mabel Srkes, Secretary.

\section{REPORT OF THE PHYSICS SECTION SESSION AT THE MEET- ING OF THE CENTRAL ASSOCIATION OF SCIENCE \\ AND MATHEMATICS TEACHERS HELD AT CLEVELAND, NOVEMBER \\ 26 AND 27, 1910.}

After an inspection of the new Technical High School of Cleveland, the physics teachers went to the third floor where an opportunity was given them to examine the exhibits of physical apparatus made by several manufacturers. At two o'clock the physics section convened in an adjoining room under the chairmanship of Mr. C. W. Spicer of Joliet, Mll.

The chair appointed as a nominating committee Mr. Turton of Chicago; Mr. Macauley, St. Charles, Ill. ; and Mr. C. M. Bronson, Toledo, O.

In the absence of Professor Reed the program was opened by Mr. Paul G. W. Keller, principal of the high school, Appleton, Wis, with a paper describing an experiment in that school in which the subject of physics is taught in two short courses instead of one long course. One course consists of a general survey of the subject in its more elementary aspects intended for those who can afford only a portion of a year for physics. The second course is more intensive and extended intended for those having more time for the subject and greater interest in it. The plan has been in operation for too short a time to justify any sweeping conclusions, but it promises great success.

The paper created considerable interest and at its close many questions were asked in regard to the plan. Professor J. O. Reed, of the University of Michigan, was the next speaker. He gave an address replete with interest on the subject, "Teaching of Physics in High School and University." This address to be appreciated needs to be read in full, and hence no analysis of it will be attempted here. At its conclusion the section on motion of $\mathrm{Mr}$. Tower of Chicago gave Dean Reed a unanimous vote of thanks for his inspiring address.

The paper on the Freeport School and Shop Cooperative Course was, in the absence of its author, Mr. Fulwider of Freeport, Ill., read by Mr. H. T. McMyler of Cleveland. In the discussion following the paper, Mr. Terry asked if anyone present bad had any experience with such a course. $\mathbf{M r}$. 